Click www.researchjournal.co.in/online/subdetail.html to purchase.

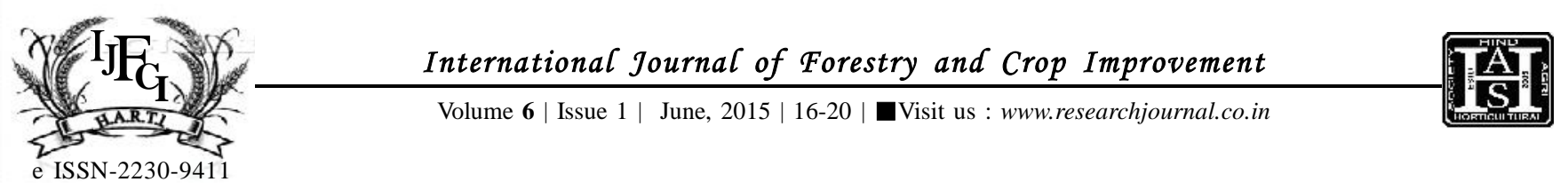

RESEARCH ARTICLE

DOI: $10.15740 / \mathrm{HAS} / \mathrm{IJFCI} / 6.1 / 16-20$

\title{
Effect of planting date and spacing on performance of marigold (Tagetes erecta Linn) cv. PUSA NARANGI under North Bihar agro-ecological conditions
}

\author{
ANIL KumAR Singh, Udit KuMAR AND ARUn KuMAR
}

\begin{abstract}
A field trial was carried out for two years to ascertain performance of marigold (var. Pusa Narangi) planted at three spacings and on six different dates at bimonthly interval i.e. on first day of March, May, July, September, November and January. The crop planted on $1^{\text {st }}$ March showed early flowering compared to other planting dates. The best performance with respect to flower size, weight and number of flowers per plant was recorded with $1^{\text {st }}$ September planting. The highest number of branches and plant canopy spread were attained with May and July plantings. In both the years wider spacing of $40 \mathrm{~cm} \times 40 \mathrm{~cm}$ produced best results with respect to maximum flower diameter, weight of individual flower and number of flower per plant. However, the total best yield per unit area was higher when the crop was planted on $1^{\text {st }} S$ eptember at $40 \mathrm{~cm} \times 20 \mathrm{~cm}$ spacing.
\end{abstract}

KEY WORDS : Marigold, Tagetes erecta Linn, Planting time, Spacing, Flower quality, Yield

HOW TO CITE THIS ARTICLE : Singh, Anil Kumar, Kumar, Udit and Kumar, Arun (2015). Effect of planting date and spacing on performance of marigold (Tagetes erecta Linn.) cv. PUSA NARANGI under North Bihar agro-ecological conditions. Internat. J. Forestry \& Crop Improv., 6 (1) : 16-20.

ArTiCle Chronical : Received : 11.11.2014; Revised : 05.04.2015; Accepted : 09.05.2015 